\title{
DISSOLUTION BEHAVIOR OF NB-RICH PRECIPITATES DURING REHEATING OF MICROALLOYED STEEL HEAVY PLATES
}

\author{
Fábio Dian Murari ' \\ Antônio Adel dos Santos ' \\ André Luiz Vasconcellos da Costa e Silva ${ }^{2}$ \\ José María Rodriguez-lbabe ${ }^{3}$
}

\begin{abstract}
The effect of reheating temperature of slabs on the dissolution of precipitates and mechanical properties of $\mathrm{Ti}-\mathrm{Nb}$ microalloyed steel was investigated in pilot scale. Transmission electron microscopy indicated a significant decrease in the presence of precipitates formed during the solidification of the steel as the reheating temperature increased from $1100^{\circ} \mathrm{C}$ to $1200^{\circ} \mathrm{C}$. With further temperature increase up to $1280^{\circ} \mathrm{C}$ no significant changes in size and shape of the precipitates were observed. Together with the precipitates dissolution behavior, an increase in strength was observed with the elevation of the reheating temperature up to $1200^{\circ} \mathrm{C}$, due in part to the reprecipitation of fine $\mathrm{Nb}$-rich precipitates during hot rolling. When reheating at $1200^{\circ} \mathrm{C}$ the presence of deformed ferrite on the microstructure contributed to the additional increase in strength. After reheating above $1200^{\circ} \mathrm{C}$ up to $1280^{\circ} \mathrm{C}$, a decrease in strength of the rolled plates was observed. This effect has been credited to the absence of deformed ferrite grains and to a small increase in the low angle grain boundaries size. The results were in agreement with Thermo-Calc and Dictra simulations.
\end{abstract}

Keywords: Reheating plates; Precipitates dissolution; Heavy plates.

\section{INTRODUCTION}

The initial stage of any hot deformation process is the reheating of the material. The objective of this step is to raise the temperature to give the necessary plasticity for the hot deformation and to dissolve the precipitates of existing microalloying elements in order to guarantee the precipitation of fine particles in the metallic matrix during hot rolling and/or cooling of the plate [1,2].

Among the main microalloying elements used, $\mathrm{Nb}$ is considered the most important. It plays a fundamental role in the majority of steels processed as heavy plates because it allows obtaining a final refined microstructure, resulting in an excellent combination of mechanical resistance and toughness properties. In addition to the grain refining effect, $\mathrm{Nb}$ also contributes to increasing the strength properties by means of the precipitation hardening mechanism. However, in order to play its full potential, the $\mathrm{Nb}$ added into the steel must be dissolved in the matrix in the end of reheating, on slab discharging $[3,4]$.

During continuous casting of $\mathrm{Ti}-\mathrm{Nb}$ microalloyed steels, coarse $(\mathrm{Ti}, \mathrm{Nb})(\mathrm{N}, \mathrm{C})$ precipitates are initially formed above $1300^{\circ} \mathrm{C}$. These particles usually appear associated with inclusions and microssegregation [5]. They are called primary precipitates and hardly dissolve under usual slab reheating conditions. After formation of these precipitates, the nucleation and growth of fine particles of $(\mathrm{Nb}, \mathrm{Ti})(\mathrm{C}, \mathrm{N})$ having different morphologies and $\mathrm{Ti} / \mathrm{Nb}$ ratios occur. As in the case of primary precipitates, the core of these precipitates is generally richer in Ti and N [5-8]. This type of precipitate can be dissolved during the reheating step, resulting in the increase of $\mathrm{Nb}$ content in solid solution in austenite before hot rolling process.

There is a large amount of knowledge available in literature $[9,10]$ to estimate the temperature required for the dissolution of $\mathrm{Nb}$-rich precipitates, $(\mathrm{Nb}, \mathrm{Ti})(\mathrm{C}, \mathrm{N})$, being very common the application of solubility product equations and the use of computational thermodynamics tools, such as Thermo-Calc software. However, these techniques deal only with the thermodynamic aspect, not considering the kinetics, that is, the time required for the dissolution.

Besides that, it is well known that the industrial reheating process is continuous, contrary to the implicit consideration normally assumed in the estimates of isothermal treatment. A further detail is that in most calculations the geometry and size of precipitates formed during the solidification of steel are not considered.

In the present work the dissolution of Nb-rich precipitates under continuous heating conditions close to those practiced in industrial process was studied on laboratory scale. The effect of reheating temperature on the microstructure and mechanical properties of $\mathrm{Ti}-\mathrm{Nb}$

'Centro de Pesquisas da Usiminas, Ipatinga, MG, Brasil. E-mail: fabio.murari@usiminas.com ${ }^{2}$ Departamento de Metalurgia e Materiais, Universidade Federal Fluminense, Volta Redonda, RJ, Brasil. ${ }^{3}$ CEIT, Donostia-San Sebastian, Spain.

2176-1523 (C) 2020. Pareda. Published by ABM. This is an Open Access article distributed under the terms of the Creative Commons Attribution License, which permits unrestricted use, distribution, and reproduction in any medium, provided the original work is properly cited. 
microalloyed steel was investigated and the precipitates dissolution behavior, evaluated by means of transmission electron microscopy, was compared with Thermo-Calc and Dictra simulations.

\section{MATERIAL AND METHODS}

\section{I Material}

The steel used in this investigation was an industrial cast of $\mathrm{Ti}-\mathrm{Nb}$ microalloyed steel. The $\mathrm{C}, \mathrm{Nb}, \mathrm{Ti}$ and $\mathrm{N}$ contents are shown in Table I. The temperatures for complete dissolution of $\mathrm{Nb}$ and Ti-rich precipitates determined by Thermo-Calc software are also shown in the table. As can be seen, the $\mathrm{Nb}$-rich precipitates dissolve totally, considering equilibrium conditions, at $1108^{\circ} \mathrm{C}$. Concerning the $(\mathrm{Ti}, \mathrm{Nb})$ (N,C) particles, the dissolution finishes at $1430^{\circ} \mathrm{C}$.

\subsection{Initial Characterization of the Precipitates}

The characterization of the precipitates formed during the solidification of steel (initial condition) was performed by scanning electron microscopy (SEM) and transmission electron microscopy (TEM). The analyses were carried out using samples taken at $1 / 2$ of the slab thickness in order to obtain the size, morphology and chemical composition of the precipitates. For precipitate size measurements Aztec software was used.

\subsection{Characterization of the Precipitates After Reheating}

Samples of $30 \mathrm{~mm}$ thickness, taken from slab center, were reheated in an electrical resistance furnace with open atmosphere, according to the curve shown in Figure I, to varied reheating temperatures. The curve used in the pilot

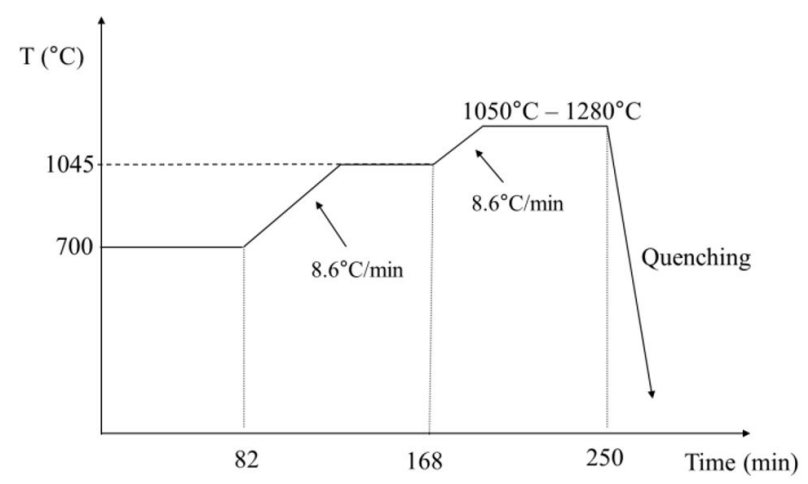

Figure I. Reheating curve used in the pilot furnace. furnace was obtained based on a typical curve employed in the industrial process for the microalloyed steel studied. This industrial curve was reproduced in the pilot furnace in terms of heating rate in the preheating, heating and soaking steps, considering the total residence furnace time applied in the industrial practice. Holding times after the ramps were used to ensure the achievement of the aim temperature values. A thermocouple was inserted in the sample mid-thickness in order to measure the material temperature. After reaching the aim reheating temperature, the samples were quenched in ice water with stirring.

The precipitates characterization was carried out at $1 / 2$ of the quenched samples thickness by means of SEM and TEM.

\subsection{Kinetics of Dissolution During the Reheating}

The Thermo-Calc software was used for the equilibrium calculations and DICTRA for the diffusion ones, both in the version 20l8b. Databases TCFE6 and MOBFE2 were used. The dissolution of carbonitrides was modeled assuming a spherical cell of austenite surrounding a precipitate of carbonitride, also spherical, according to the work by Borba et al. [I I].

In the DICTRA simulation, the input parameters were the precipitate and austenitic matrix radii and the chemical composition of the calculated phases in Thermo-Calc, starting from the simplified chemical composition shown in Table I.

The mean particle radius used was obtained from measurements of the carbonitride diameter distribution using the Aztec software. Three simulations were performed, with different precipitate diameters: $100 \mathrm{~nm}$, which in the as-cast condition represented the highest frequency in the distribution, $280 \mathrm{~nm}$ and $500 \mathrm{~nm}$.

The diameter of the austenite cell was calculated so as to match the volume fraction of the two phases, considering the diameter chosen for the precipitate. In the simulation, temperature ranged from $910^{\circ} \mathrm{C}$ (austenite stability region) to $1280^{\circ} \mathrm{C}$, according to the parameters shown in Figure 2. In this case, no holding times after the ramps were used and heating rates were closer to those obtained in the samples heated in the furnace.

\subsection{Hot Rolling}

In order to examine the influence of reheating temperature on the microstructure and mechanical properties of hot rolled plates, samples of $125 \mathrm{~mm}$ thickness taken from the center of slab thickness, which is the most critical place in terms of dissolution of precipitates, were heated under the same conditions shown in Figure I. After discharging, they were hot rolled using conditions as close as possible to

Table I. Chemical composition of the microalloyed steel used (wt.\%) and dissolution temperatures (DT) of Nb and Ti-rich precipitates

\begin{tabular}{ccccccc}
\hline $\mathbf{C}$ & $\mathbf{N b}$ & $\mathbf{T i}$ & $\mathbf{N}$ & $\mathbf{T i} / \mathbf{N}$ & $\mathbf{D T}_{(\mathrm{Nb}, \mathrm{Ti})(\mathrm{C}, \mathbf{N})}$ & $\mathbf{D T}(\mathrm{Ti}, \mathbf{N b})(\mathrm{N}, \mathrm{C})$ \\
\hline 0.087 & 0.019 & 0.024 & 0.0035 & 6.86 & $1108^{\circ} \mathrm{C}$ & $1430^{\circ} \mathrm{C}$ \\
\hline
\end{tabular}


industrial process (controlled rolling followed by air cooling). All samples were submitted to the same pass schedule, which resulted in the same final thickness $(18 \mathrm{~mm})$.

\subsection{Microstructural Characterization}

Longitudinal sections of the rolled plates were prepared following standard metallographic procedures and examined by scanning electron microscopy.

Aiming at quantifying the mean crystallographic unit sizes, electron backscatter diffraction (EBSD) scans were carried out on the hot rolled samples. Apart from mean size, unit size distributions have also been quantified. Different imaging options (inverse pole figure and grain boundary) were analyzed and crystallographic unit sizes were measured

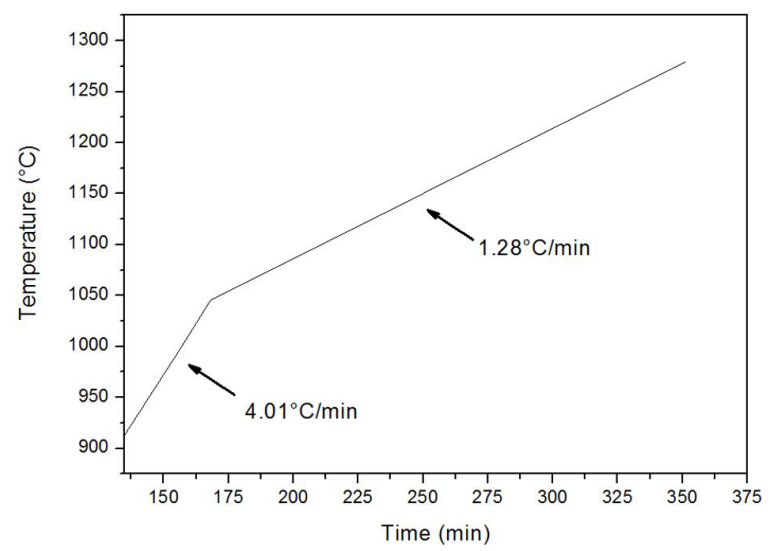

Figure 2. Reheating curve used in the Dictra simulations.

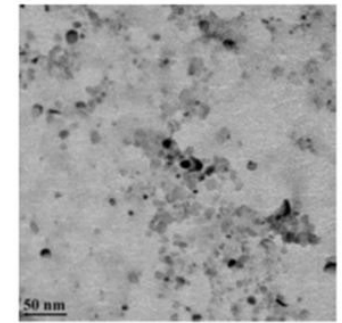

(a)

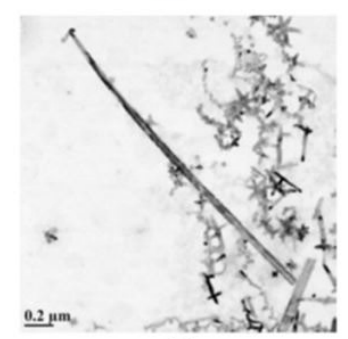

(c)

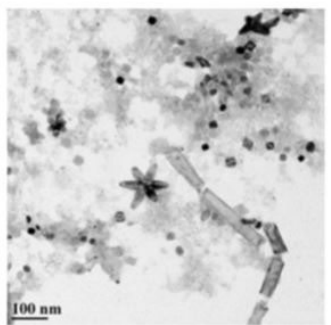

(b)

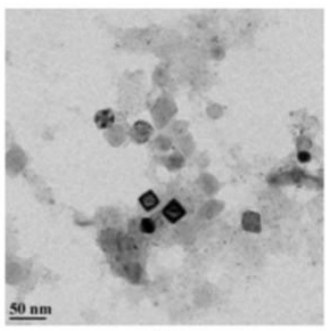

(d) considering different misorientation criteria: (i) $4^{\circ}<\vartheta<15^{\circ}$ (low angle grain boundaries - D4 $4^{\circ}$ ): it corresponds to the unit size controlling strength; (ii) $\vartheta>15^{\circ}$ (high angle grain boundaries $-\mathrm{D}\left(5^{\circ}\right)$ : this unit size is the main feature controlling toughness [12]. In addition to quantification of unit size, hardening due to dislocation density has to be considered. In this study, dislocation density has been evaluated from Kernel average misorientation obtained in EBSD. For the quantification of ferrite grain size, the secondary phase (pearlite) has been deleted from the obtained scans.

\subsection{Mechanical Properties}

Tensile specimens with $25 \mathrm{~mm}$ gauge length transversal to rolling direction were machined for evaluation of the mechanical properties. The tests were carried out in an electromechanical INSTRON 5882 test machine, at a constant strain rate of $10^{-3} / \mathrm{s}$.

\section{RESULTS AND DISCUSSION}

\section{I Precipitates in Slab}

Abundant presence of $\mathrm{Nb}$-rich precipitates was verified, often in the form of agglomerates, Figure 3. Cruciform (20-200 nm), rectangular/cubic $(20-600 \mathrm{~nm})$, elongated $(20-200 \mathrm{~nm})$, needle (more than $500 \mathrm{~nm}$ length) and very fine spherical $(<10 \mathrm{~nm})$ shaped precipitates were also found. Analyses performed via energy dispersive spectrometer (EDS) showed that the particles were rich in $\mathrm{Nb}$ and $\mathrm{Ti}$, with different $\mathrm{Nb} / \mathrm{Ti}$ ratios, Figures $3 \mathrm{e}$ and $3 \mathrm{f}$. As mentioned

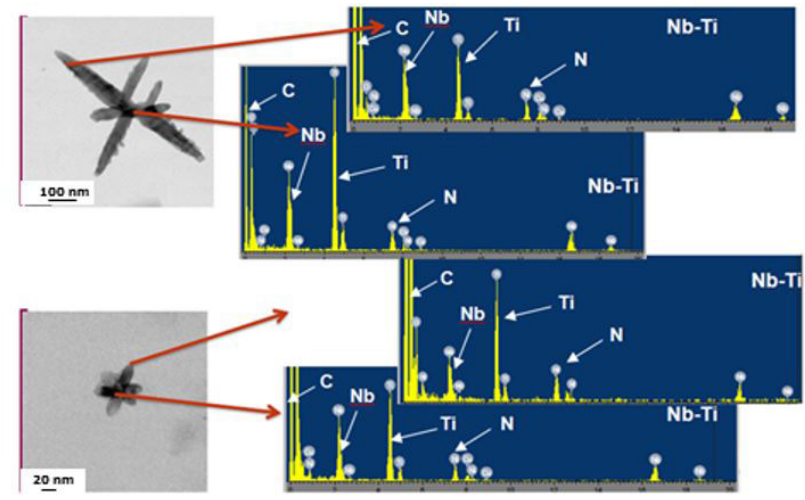

(e)

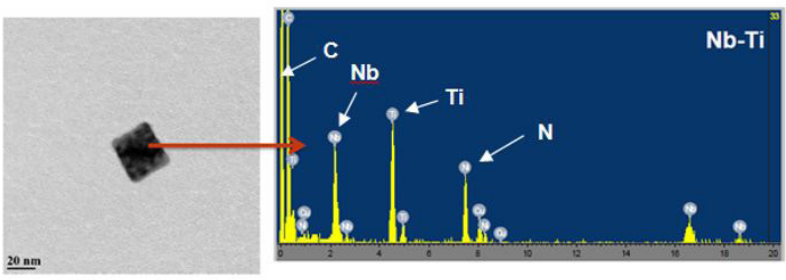

(f)

Figure 3. Types of precipitates observed by TEM on carbon extraction replicas: (a) agglomerates of fine spherical; (b) Cruciforms, stars and rectangular/cubic shaped; (c) Needle, cruciform and star shaped; (d) Cubic; (e) EDS results in cruciform precipitates; (f) EDS results in a cubic precipitate. 
earlier, a higher frequency of $\mathrm{Nb}$-rich precipitate sizes up to $100 \mathrm{~nm}$ was observed. Coarse precipitates, larger than $500 \mathrm{~nm}$, were richer in $\mathrm{Ti}$.

\subsection{Precipitates Dissolution During the Reheating}

As can be seen from Figure 4, a high number of undissolved $\mathrm{Nb}$-Ti rich particles were noticed at the lowest reheating temperatures of $1050^{\circ} \mathrm{C}$ and $1100^{\circ} \mathrm{C}$. Cubic/oval/ spherical and cruciform/star/needle shaped precipitates were observed, besides the coarse precipitates richer in $\mathrm{Ti}$ and $\mathrm{N}$ (primary precipitates). The precipitation state was very similar to the one noticed in the as cast condition. At $1175^{\circ} \mathrm{C}$ it is possible to note that the cruciform/star/needle shaped precipitates and the very fine spherical precipitates were dissolved during the reheating process. Only cubic and rectangular precipitates $(>50 \mathrm{~nm})$ were found, besides coarser oval/spherical particles, likely remaining nuclei of cruciform precipitates. Precipitates found at $1200^{\circ} \mathrm{C}$ were only those cubic shaped with edge size larger than $50 \mathrm{~nm}$ (primary precipitates). These particles were observed in an isolated form or in agglomerates. The precipitation behaviors at $1250^{\circ} \mathrm{C}$ and $1280^{\circ} \mathrm{C}$ were similar to the one found at $1200^{\circ} \mathrm{C}$. Apparently, it seems there was no additional

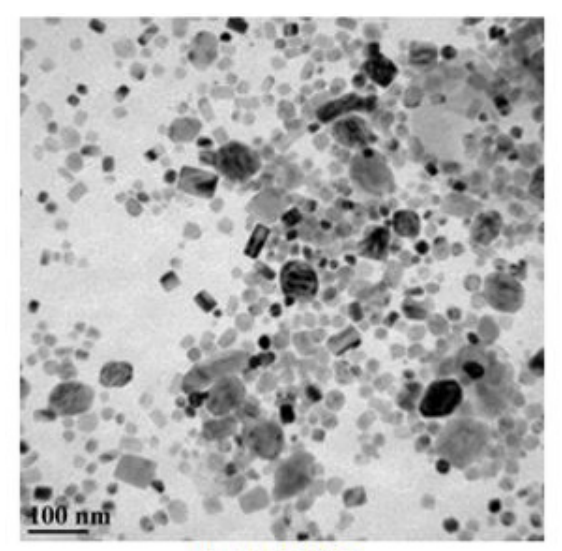

(a) $1050^{\circ} \mathrm{C}$

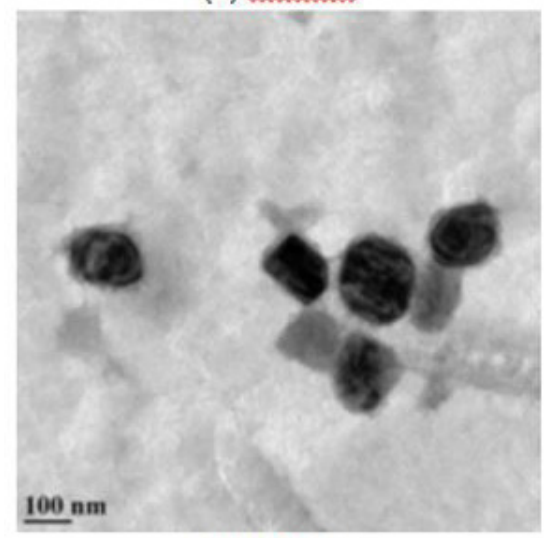

(c) $1175^{\circ} \mathrm{C}$

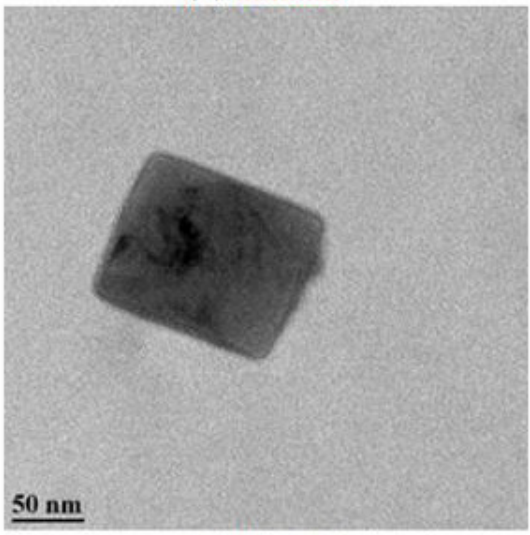

(e) $1250^{\circ} \mathrm{C}$

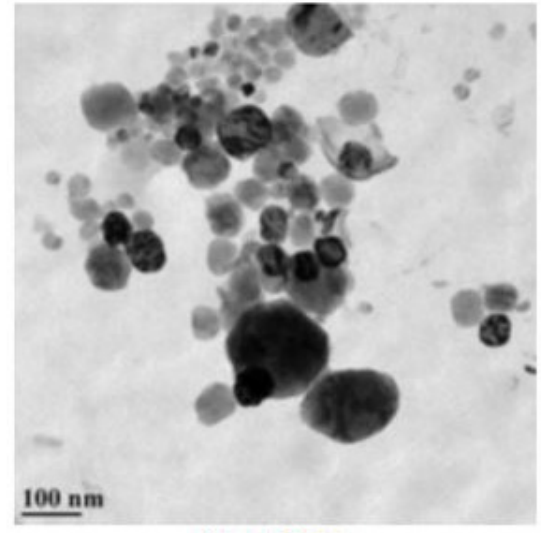

(b) $1100^{\circ} \mathrm{C}$

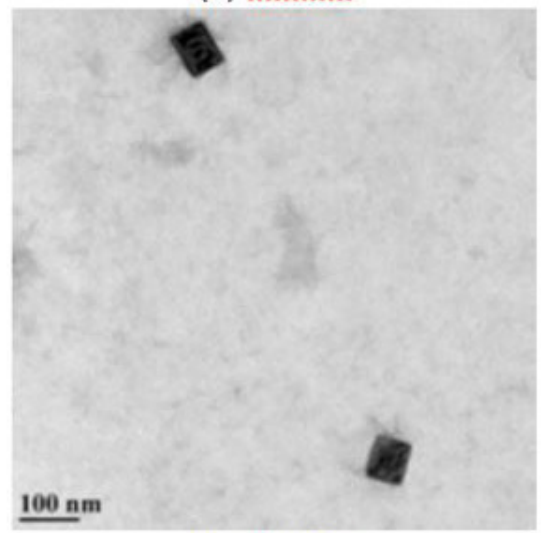

(d) $1200^{\circ} \mathrm{C}$

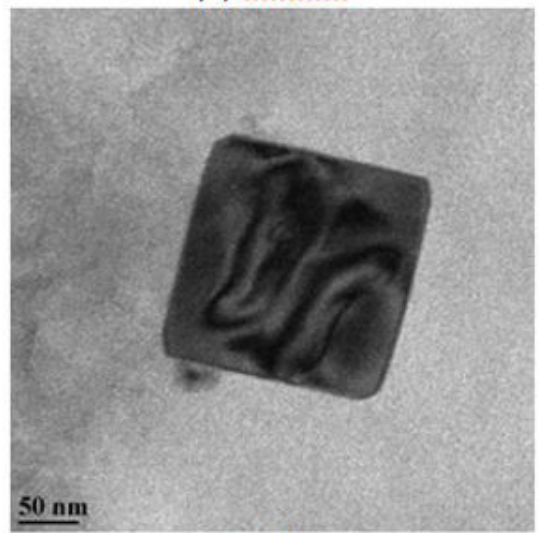

(f) $1280^{\circ} \mathrm{C}$

Figure 4. Effect of reheating temperature on $\mathrm{Ti}-\mathrm{Nb}$ precipitates dissolution. 
change in form and size of these precipitates. The only change observed was a reduction in the $\mathrm{Nb}$ content as the temperature increased, Figure 5.

\subsection{Dissolution Kinetics of Nb-rich Precipitates}

The variations of $\mathrm{Nb}$-rich precipitate diameter and dissolved $\mathrm{Nb}$ with time and temperature, calculated with Dictra, are shown in Figures 6a and 6b, respectively. As can be seen, for the heating conditions used, the dissolution occurs in the soaking region, above $1000^{\circ} \mathrm{C}$. However, the dissolution process does not finish at $1108^{\circ} \mathrm{C}$ as predicted by Thermo-Calc. For $100 \mathrm{~nm}$ diameter precipitates $\left(\mathrm{D}_{\mathrm{ppt}}\right)$, the total dissolution (TD) is reached at $1137^{\circ} \mathrm{C}$ after $72 \mathrm{~min}$ of soaking $\left(\mathrm{t}_{\text {soak }}\right)$, Table 2 . Increasing their diameter to $280 \mathrm{~nm}$ and $500 \mathrm{~nm}$ results in an increase of the TD and $\mathrm{t}_{\text {soak }}$ required for the complete dissolution. Considering the biggest particle, $500 \mathrm{~nm}$, the complete dissolution is reached at $1228^{\circ} \mathrm{C}$

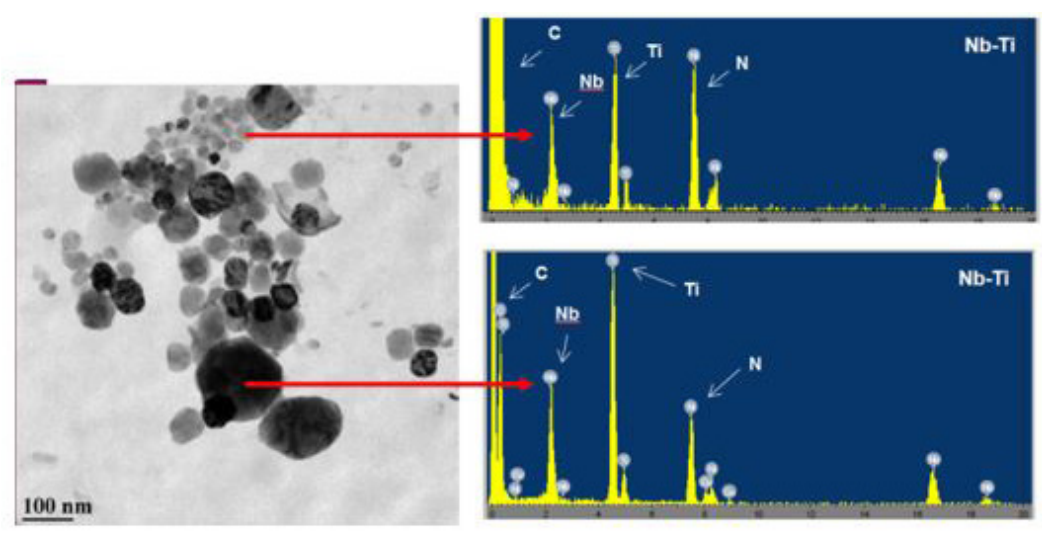

(a)

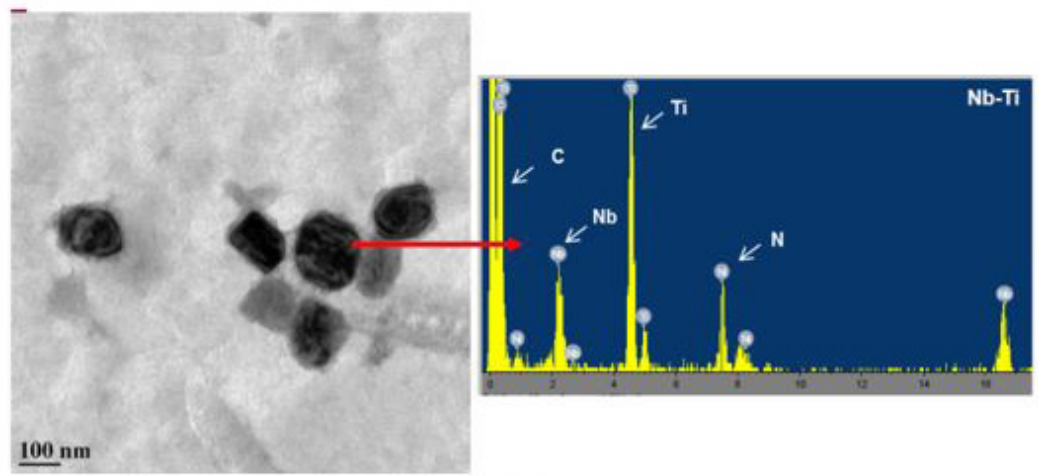

(b)

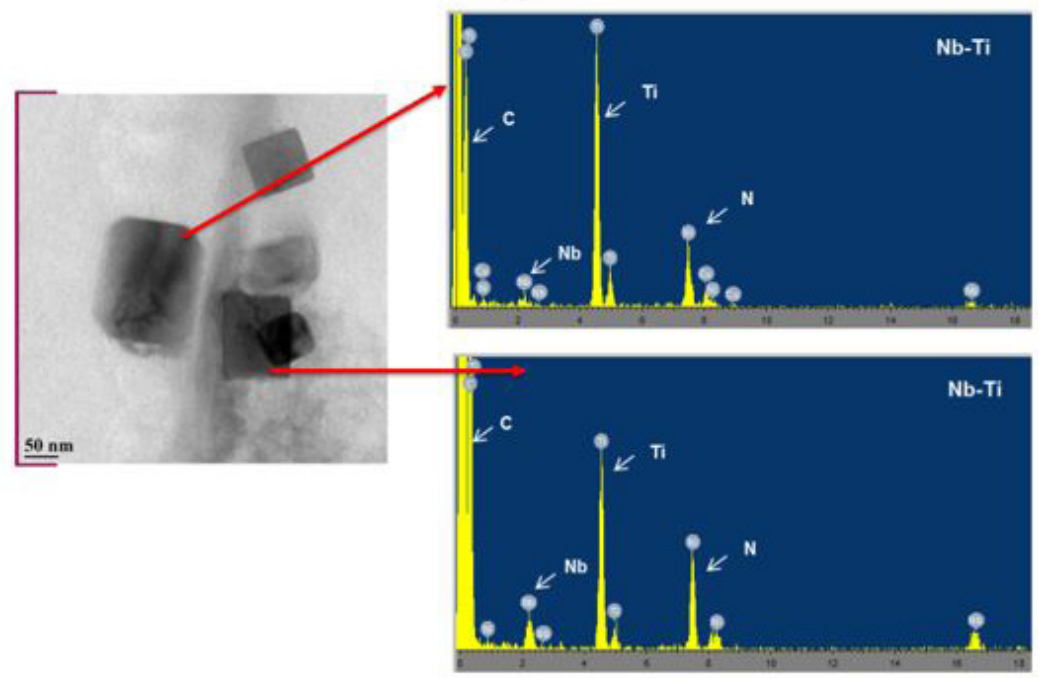

(c)

Figure 5. EDS analyses in precipitates found at (a) $1100^{\circ} \mathrm{C}$; (b) $1175^{\circ} \mathrm{C}$; and (c) $1280^{\circ} \mathrm{C}$. 

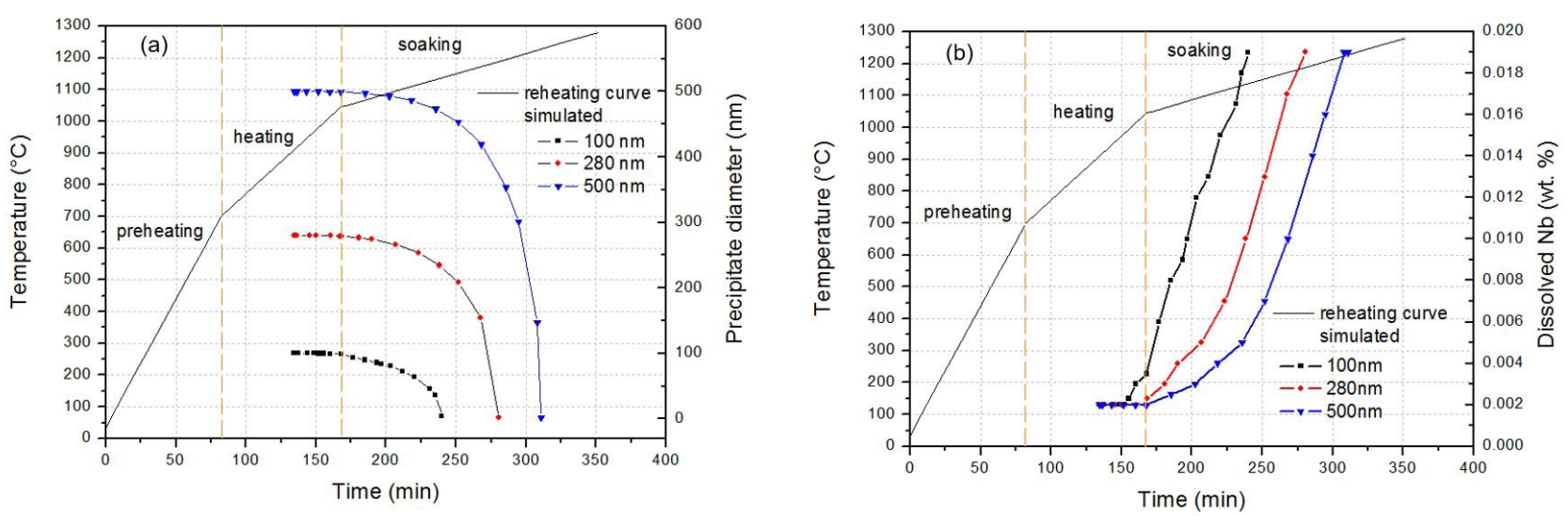

Figure 6. Evolution of $\mathrm{Nb}$-rich precipitate diameter (a) and of dissolved $\mathrm{Nb}$ (b) with time and temperature.

Table 2. Reheating conditions for complete dissolution of Nb-rich precipitates

\begin{tabular}{cccc}
\hline \multirow{2}{*}{$\mathbf{D}_{\mathbf{p p t}}(\mathbf{n m})$} & \multicolumn{3}{c}{ Complete dissolution } \\
\cline { 2 - 4 } & $\mathbf{T D}\left({ }^{\circ} \mathbf{C}\right)$ & $\mathbf{t}_{\text {soak }}(\mathbf{m i n})$ & $\mathbf{t}_{\text {furn }}(\mathbf{m i n})$ \\
\hline 100 & 1137 & $72 \mathrm{~min}$ & $240 \mathrm{~min}$ \\
280 & 1189 & $112 \mathrm{~min}$ & $281 \mathrm{~min}$ \\
500 & 1228 & $142 \mathrm{~min}$ & $311 \mathrm{~min}$ \\
\hline
\end{tabular}

after 142 min of soaking, which results in a total furnace residence time $\left(\mathrm{t}_{\text {furn }}\right)$ of $311 \mathrm{~min}$. These results indicate that it is very important to obtain fine $\mathrm{Ti}-\mathrm{Nb}$ precipitates after steel solidification through adequate alloy design and processing conditions. Thus, the $\mathrm{Nb}$-rich precipitates can be dissolved under usual reheating conditions and the Ti-rich precipitates will, instead, be more effective in restricting the austenitic grain growth.

\subsection{Effect of Precipitates Dissolution on Microstructure}

The effect of reheating temperature on microstructure is shown in Figure 7. Concerning Kernel maps, the color selection done indicates that as the color becomes closer to blue, the dislocation density is lower, while the opposite occurs when more yellow-red color areas appear. Therefore, ferritic recrystallized grains should have quite close to blue-green color. There was a reduction of $\mathrm{D} 4^{\circ}$ with increasing reheating temperature up to $1200^{\circ} \mathrm{C}$. After that, an opposite behavior was observed. On the other hand, $D 15^{\circ}$ decreased continuously as the reheating temperature increased.

In the sample reheated to $1200^{\circ} \mathrm{C}$, different ferrite populations are observed in the final microstructure. Combinations between non-deformed and deformed ferrite are clearly distinguished. High fraction of deformed ferrite can be observed in the grain boundary map, which is characterized by a significant presence of substructure (low angle boundaries represented in red). This suggests that the deformation was applied in the intercritical $\gamma / \alpha$ region, introducing significant differences in the final microstructure and mechanical behavior.
The accumulated area fraction of $\mathrm{D} 4^{\circ}$ and $\mathrm{D} 15^{\circ}$ is shown in Figures $8 \mathrm{a}$ and $8 \mathrm{~b}$, respectively. As can be observed, the increase of reheating temperature raised the area fraction of $\mathrm{D} 4^{\circ}$, which can be associated to the $\mathrm{Nb}$ precipitates dissolution behavior. Concerning $\mathrm{DI} 5^{\circ}$, there is also a trend of raising it as the reheating temperature increases, except at $1200^{\circ} \mathrm{C}$ due to the presence of non-deformed ferrite in the microstructure. As mentioned before, for toughness the $\mathrm{DI} 5^{\circ}$ average grain size and volume fraction are the most important factors. So, for a good balance between strength and toughness the intercritical rolling should be avoided.

The variation of mean grain size with reheating temperature is shown in Figure 8c. The reduction of the reheating temperature promoted the formation of coarser microstructures. This could be associated with lower contents of $\mathrm{Nb}$ in solid solution as the reheating temperature decreased.

\subsection{Effect of the Precipitates Dissolution on the Mechanical Properties}

The effect of reheating temperature on mechanical properties can be observed in Figure 9. The yield strength and the tensile strength increased with temperature up to $1200^{\circ} \mathrm{C}$, due to dissolution of $\mathrm{Nb}$ and subsequent fine reprecipitation during hot rolling. At $1200^{\circ} \mathrm{C}$ the presence of deformed ferrite on the microstructure contributed to the additional increase of strength. It is worth noting an increase greater than $100 \mathrm{MPa}$ in the yield and tensile strength values from $1050^{\circ} \mathrm{C}$ to $1200^{\circ} \mathrm{C}$. Further increase in reheating temperature resulted in strength drop, which may have been caused by the absence of deformed ferrite grains and also by a small increase in $\mathrm{D} 4^{\circ}$ average grain size. Concerning the total elongation, the lowest value is observed at $1150^{\circ} \mathrm{C}$ followed by an increase with temperature up to $1250^{\circ} \mathrm{C}$. Beyond this, another drop is observed. This behavior does not fully agree with the yield and tensile strength results. Reduction in total elongation was expected up to $1200^{\circ} \mathrm{C}$ followed by a small increase up to $1280^{\circ} \mathrm{C}$. The reasons for this discrepancy remain to be investigated. 


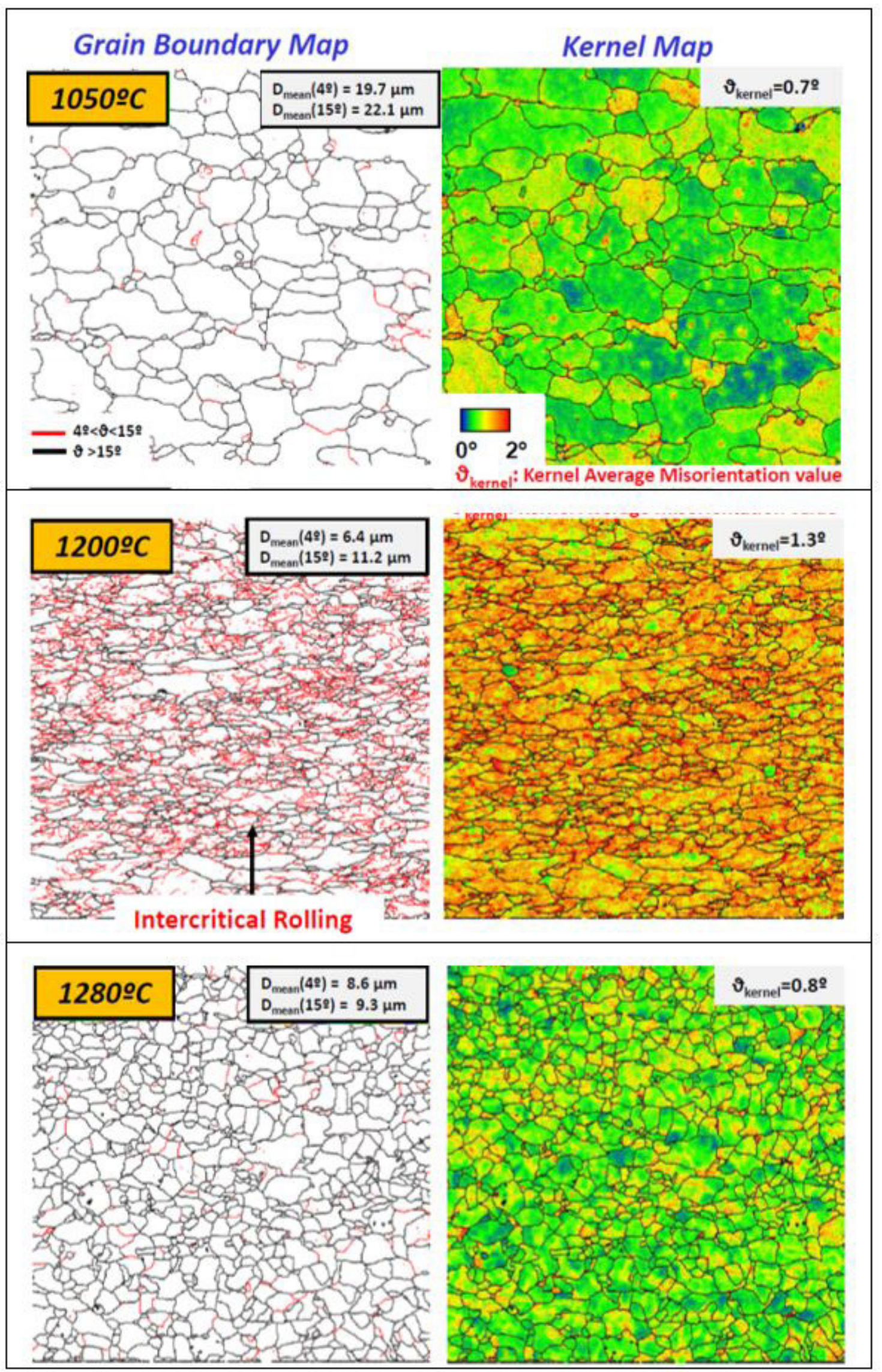

Figure 7. Microstructure of the hot rolled samples reheated to different temperatures. 


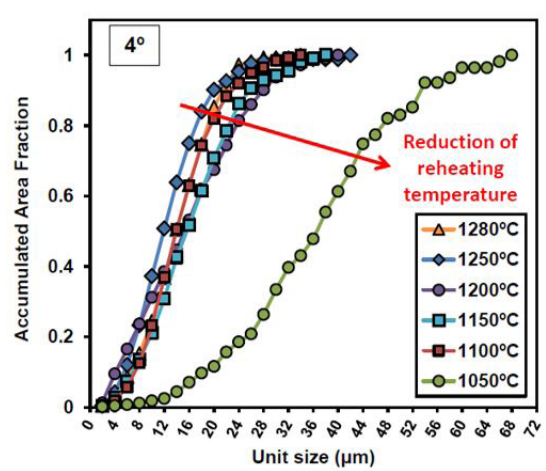

(a)

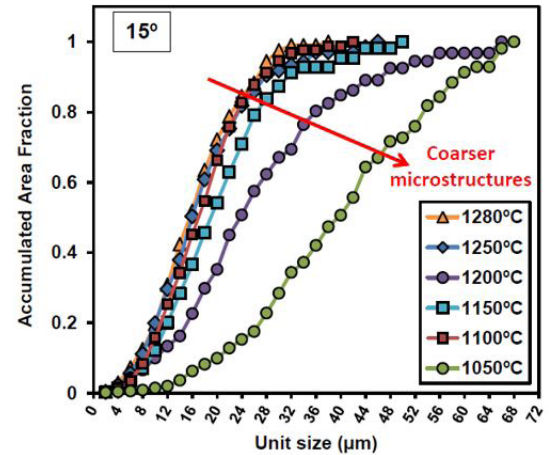

(b)

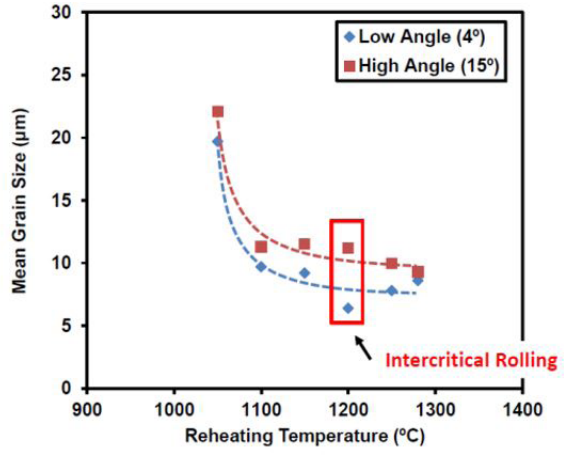

(c)

Figure 8. Effect of reheating temperature on accumulated area fraction of $D 4^{\circ}(a)$ and $D I 5^{\circ}(b)$, and on mean grain size, (c).

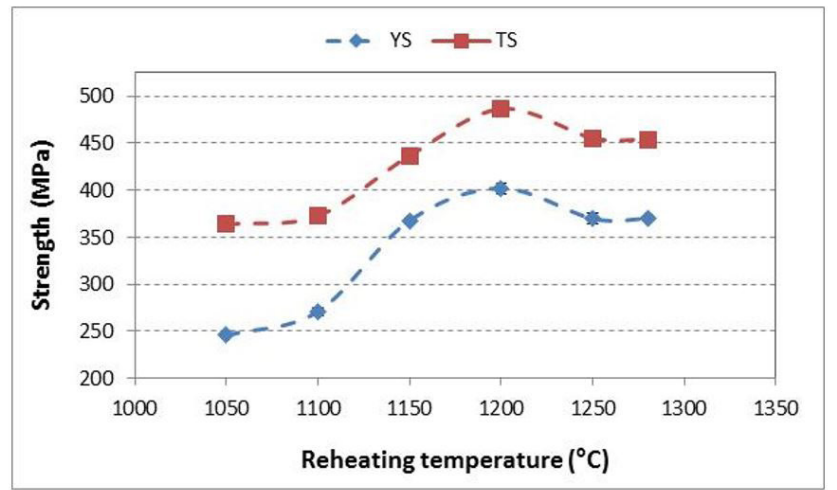

(a)

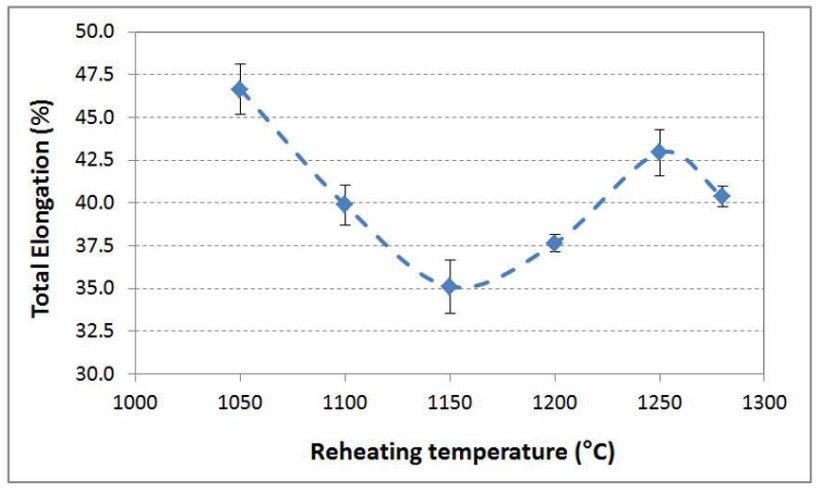

(b)

Figure 9. Variation of yield strength (YS) and tensile strength (TS) (a) and total elongation (b) with reheating temperature.

\section{CONCLUSIONS}

The dissolution behavior of Nb-rich precipitates in a microalloyed steel was studied in laboratory scale using continuous heating conditions close to those practiced in industrial process of slab reheating.

It was observed by means of transmission electron microscopy that the dissolution of $\mathrm{Nb}$-rich precipitates occurred almost totally in the soaking region of the reheating furnace, above $1000^{\circ} \mathrm{C}$, and finished in the temperature range $1150-1200^{\circ} \mathrm{C}$, which is higher than that predicted by Thermo-Calc software (dissolution temperature equals to $1108^{\circ} \mathrm{C}$ in equilibrium condition). This is probably due to dissolution kinetic reasons.

In line with these results, the mechanical strength increased with temperature up to $1200^{\circ} \mathrm{C}$, due to dissolution of $\mathrm{Nb}$ and subsequent fine reprecipitation during hot rolling. The associated refinement of the microstructure also contributed to the increase in strength. Besides that, deformed ferrite in the microstructure of the sample reheated to $1200^{\circ} \mathrm{C}$ was verified, leading to additional increment in yield and tensile strength. After reheating above $1200^{\circ} \mathrm{C}$ up to $1280^{\circ} \mathrm{C}$, a decrease in strength of the rolled plates was noticed. This effect has been credited to the absence of deformed ferrite grains and to a small increase in the low angle grain boundaries size.

These findings indicate that it is very important to obtain fine $\mathrm{Ti}-\mathrm{Nb}$ precipitates in the as cast slab condition through an adequate alloy design and processing conditions. This way, the Nb-rich precipitates can be dissolved under usual reheating conditions and the Ti-rich precipitates will be more effective at restricting the austenitic grain growth.

Finally, an attempt to model the kinetics of $\mathrm{Nb}$ precipitates dissolution was made using Dictra software, assuming a spherical cell of austenite surrounding a carbonitride precipitate, also spherical. The results obtained were in good agreement with observed precipitates by microscopy and also with mechanical properties of rolled plates. Despite the assumptions, the used methodology allowed to evaluate the effect of steel chemical composition and slab reheating strategy on dissolution kinetics, in order to optimize the use of $\mathrm{Nb}$ during hot rolling process.

\section{Acknowledgements}

The authors are grateful to the CBMM for support in EBSD and TEM analyses. 


\section{REFERENCES}

I Jun HJ, Kang KB, Park CG. Effects of cooling rate and isothermal holding on the precipitation behavior during continuous casting of Nb-Ti bearing HSLA steels. Scripta Materialia. 2003;49(I I): I08I-I086.

2 Murari FD, Santos AA, Gusmão AMR, Pereda B, Lopez B, Rebellato MA. Heating rate effect on the precipitates dissolution and mechanical properties of microalloyed steel plates. Rolling and Metal Forming Seminar. 2018;55(55):525-536.

3 Zheng S, Davis C, Strangwood M. Elemental segregation and subsequent precipitation during solidification of continuous cast Nb-V-Ti high-strength low-alloy steels. Materials Characterization. 20 I4;95:94- 104.

4 Nishioka K, Ichikawa K. Progress in thermomechanical control of steel plates and their commercialization. Science and Technology of Advanced Materials. 2012; 13:1-20.

5 Chen Z, Loretto MH, Cochrane RC. Nature of large precipitates in titanium-containing HSLA steels. Materials Science and Technology. 1987;3(10):836-844.

6 Carboni MC, Mesquita RA, Cruz EB, Fridman DP, Nogueira MAS. Characterization of precipitates in segregated regions of a Nb bearing API-X70 microalloyed steel. In: Proceedings of the 42nd ABM Steelmaking Seminar; 20I I; Salvador, Brasil. São Paulo: ABM; 20II. p. 476-488.

7 Chakrabarti D, Davis C, Strangwood M. Development of bimodal grain structures in Nb-containing high-strength low-alloy steels during slab reheating. Metallurgical and Materials Transactions A, Physical Metallurgy and Materials Science. 2008;39(8): 1963-1977.

8 Rodriguez-lbabe JM. The role of microstructure in toughness behavior of microalloyed steels. Materials Science Forum. 1998;284-286:5I-62.

9 Schiavo CP, Gonzalez BM, Santos AA, Marra KM. Influence of solubilization parameters: soaking temperature and time, on Tnr of microalloyed (Nb, V and Ti) steel. Tecnologica em Metalurgia, Materiais e Mineração. 20I I;8(I):I418.

10 Ding W, Stalheim D, Li S, Bai X, Jiang Z, Li J, et al. Research and development in the low temperature toughness of large diameter heavy wall X80 pipeline steel at Shougang Steel. In: Proceedings of the 9th International Pipeline Conference; 2012; Calgary, Alberta, Canada. New York: American Society of Mechanical Engineers; 2012. p. 249-255.

I I Borba EC, Castro CSB, Escobar DMP, Murari FD, Taiss EJM, Silva ALVC, et al. A study of the dissolution of precipitates during microalloyed steels reheating using computational thermodynamics. In: Anais do $72^{\circ}$ Congresso Anual da ABM; 2017; São Paulo. São Paulo: ABM; 2017. p. 2054-2063.

12 Uranga P, Isasti N, Rodriguez-lbabe JM, Stalheim D, Kendrick V, Frye B, et al. Optimized cost-effective production of structural hot rolled CSP coils through proper austenite conditioning. Proceedings of AISTech. 2017;2017:29752987.

Received: 4 Nov. 2019

Accepted: 7 Nov. 2019 